\title{
Analysis of Facilities and Power Competency on Implementation of Safety and Health Work in Puskesmas District of Tulungagung
}

\author{
Siswanto $^{1}$ \\ ${ }^{1}$ Magister of Health Study \\ Program of STIKes Surya Mitra \\ Husada Kediri \\ boendy66@gmail.com
}

\begin{abstract}
Occupational health services shall be an effort to provide occupational health and safety protection to workers' communities, which have the objective of maintaining and improving the health status of the working-class community, Preventing the occurrence of health problems and protecting workers from health hazards and placing workers in the work environment in accordance with their physical and psychological abilities workers. Objective Analysis research is to analyze the completeness of facilities, workforce competencies to the implementation of Occupational Health and Safety in Puskesmas District of Tulungagung. The design used in the study was cross-sectional. The population is Puskesmas District of Tulungagung. The sample size was 32 respondents Health Center by using simple random sampling technique. Independent research variables are Infrastructure and Labor Competencies. The dependent variable is the implementation of Safety Management. Data was collected using kuesoner, then the data were analyzed using linear regression test with a significance level of $\alpha \leq$ 0.05 . The results showed more than half of the health center has the facilities and infrastructure K3 (Occupational Health and Safety Management) is complete as many as 23 respondent's health centers $(76.7 \%)$, more than half Puskesmas. as having the competence K3 Officers who are not trained as much as 23 respondents health centers $(76.7 \%)$. more than half of Puskesmas.have health and safety management that less as much as 19 respondent of health center $(63,3 \%)$.
\end{abstract}

Keywords : Competence, Facilities, Occupational Health.

Copyright $@ 2018$ STIKes Surya Mitra Husada

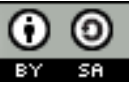

This is an open-acces article distributed under the terms of the Creative Commons Attribution-ShareAlike 4.0 International License. 


\section{INTRODUCTION}

Public Health Center (PHC) is a leading health care functional unit as a technical implementation unit DHO or city that implement educational efforts, prevention and treatment of cases of the disease in its territory, in integrated and coordinated. As a Technical Implementation (UPTD) health centers have responsibilities in organizing health development program in the working area and has an obligation to provide services to the public health community, including the worker (Department of Health, 2004). Occupational health is a matter of each individual because work takes everyone as a source of income to meet the necessities of life (Kurniawidjaja, 2010). Efforts to occupational health services is an effort in the provision of health protection and safety for working people, which has the goal of maintaining and improving public health workers, prevent illness and protect workers from health hazards as well as putting workers in a work environment in accordance with the physical ability and psychic workers.

The World Health Report 2002 puts the risk of occupational diseases in the tenth as the cause of illness and death. Meanwhile, according to a report by the International Labor Organization (ILO) in 2003 every year there are 2 million people died, 160 million cases of Occupational Diseases (PAK), Disease Due to Employment (Pahk), 270 million cases of Occupational Accidents (TOR). This event is equivalent to 1.25 trillion dollars, or $4 \%$ of world GDP. Of the 27 countries monitored by the ILO (2001), the mortality, morbidity and accidents in Indonesia are in position 26. While the data from the Social Security (2003) are known to occur every weekday worker deaths from 400 cases of occupational accidents with $9.83 \%$ ( 10393 cases) disability and forced unable to work again. This represents the reported figures, while the actual number is not known with certainty. August of 2009 BPS data showed that there were 113.89 million labor force in Indonesia. While working as much as 104.87 million were working in various jobs with the problems arising from work (Department of Health, 2013).

Lusianawati research results (2013) on the implementation of occupational health and safety (K3) at health centers showed that the implementation of K3, 58\% health centers and the implementation of the periodic medical examination / screening of TB by $56 \%$ PHC. K3 related health promotion tools are lacking only $26 \%$ of health centers (Lusianawaty, 2013). Personal protective equipment such as gloves (98\% PHC) and mask (96\% PHC) is available on almost all health centers. Infrastructure is still less present in $68 \%$ of health center and lab infrastructure are still lacking in $40 \%$ of PHC. Application of K3 at the health center needs to be improved by equipping the facilities and infrastructure health centers and laboratories, as well as a health promotion tool (Lusianawaty, 2013). The maintenance and improvement of health for capacity building and preventive work is important in reducing the prevalence of workplace accidents still neglected. Officials are still limited skills as well as medical equipment and technical environment. Results of a preliminary study on the study results showed that PHC Sembung Tulungagung safety infrastructure is not complete, the person in charge has not penah training program $\mathrm{K} 3$.

The participation of a person in an activity in the management of occupational health programs in PHC is closely related to knowledge, attitude and practices of the perpetrators (Notoatmodjo, 2010). Occupational health at the health center has a joint effort of society in accordance with the local health environment, health centers so that people and employees can help themselves in the field of occupational health and identify hazards or potential hazards in the workplace in particular clinic. Labor are at risk of illness or accident while commuting, working, and return to work, so expect workers produce optimal occupational health (Susilawaty, 2007). PHC in occupational health play a role through the process of improving the quality of health personnel to be more responsive and able to empower its clients, so that it will achieve quality occupational health services, fair and equitable. UU no. 36 of 2009 on health, especially chapter XII of occupational health in Article 164-166, stating the purpose, objectives, roles and responsibilities of governments, obligations and responsibilities of the manager of the workplace, employers and obligations of workers in occupational health efforts. Occupational health efforts aimed at protecting the workers to live 
healthy and free from health problems as well as the bad influence caused by the occupation in order to achieve optimal productivity. K3 Implementation needs to be improved by equipping the facilities and infrastructure of health centers and laboratories, as well as a health promotion tool (Lusianawaty, 2013). What happened if safety and health at the health center is not capable of being upgraded, it can have an impact on occupational accidents for employees and also for patients who receive health care at the health center.

Occupational health programa PHC program development effort means that the health measures established under the health problems found in the community as well as tailored to the ability of PHC (Minister of Health, 2014). Occupational health organized so that each worker can work in a healthy manner without endangering himself and the people around him, to obtain optimum productivity, in line with labor protection program in which every workplace must hold occupational health. The participation of a person in an activity in the management of occupational health program at the health center effort is closely related to knowledge, attitude and practices of the perpetrators. Knowledge of the benefits of an activity in the program will cause a person to have a positive attitude. Furthermore, this positive attitude will affect one's intention to participate in the activities. Public Health Center (PHC) is one of the health care institution which is a Technical Implementation Unit (UPTD) which has responsibility for delivering health development program in the working area and has an obligation to provide health services to the people including the working population (Rahayuningsih, 2010),

Results of a preliminary study in Tulungagung Sembung Health Center found that the implementation of the activities in addressing occupational health assume that the occupational health program is a program of overall health centers, so it does not need to be implemented specifically. Officer or employee in the health centers and assumed inability of officers in conducting due to lack of knowledge and skills of personnel management process program. Lack of facilities and equipment support activities are part of the blockade to the practice of occupational health programs in the clinic is the reason most often expressed by officers and employees in the health center. Based on the above problems of course, we need to realize that in the scope of work in the health sector has a lot of risks to workers. PHC in improving $\mathrm{K} 3$ needs to be supported by means $\mathrm{K} 3$ complete, trained personnel and the implementation of K3 good. Such efforts can be done by organizing health center aik in the implementation of K3 program. Based on the above data and studies researchers interested in studying about the Analysis of How to Analyze completeness of facilities, workforce competencies to the Implementation of the Occupational Health and Safety in Health Center Se-Tulungagung.

\section{METHODS}

The design used in the study was cross-sectional. The population is Puskesmas District of Tulungagung. The sample size was 32 respondents Health Center by using simple random sampling technique. Independent research variables are Infrastructure and Labor Competencies. The dependent variable is the implementation of Safety Management. Data was collected using kuesoner, then the data were analyzed using linear regression test with a significance level of $\alpha \leq 0.05$.

\section{RESULTS}

Table 1. Infrastructures Safety Puskesmas District of Tulungagung $(\mathrm{n}=30)$

\begin{tabular}{clcc}
\hline No. & facilities and infrastructure & Frequency & Percentage \\
\hline 1 & Full & 7 & 23.3 \\
\hline 2 & Not Full & 23 & 76.7 \\
\hline & Total & $\mathbf{3 0}$ & $\mathbf{1 0 0}$ \\
\hline
\end{tabular}


The results showed that the number of respondents at 30 health centers health centers. Based on the results of the investigation, as the table above shows that more than half of the health center has the facilities and infrastructure of occupational safety and health as much as 23 respondents who complete health center $(76.7 \%)$.

Table 2. Personnel Competency Occupational Health and Safety in Puskesmas District of Tulungagung $(\mathrm{n}=30)$

\begin{tabular}{ccccc}
\hline No. & & Competence & Frequency & Percent \\
\hline 1 & 1trained & 23 & 76.7 \\
\hline 2 & Trained & 7 & 23.3 \\
\hline & Total & $\mathbf{3 0}$ & $\mathbf{1 0 0}$ \\
\hline
\end{tabular}

The results showed that the number of respondents at 30 health centers health centers. Based on the results of the investigation, as the table above shows that more than half the health center has officers with occupational health and safety competencies are not trained as much as 23 respondents Health Centers $(76.7 \%)$.

Table 3. Occupational Health and Safety Management in Tulungagung Health Center $(n=30)$

\begin{tabular}{llcc}
\hline No & $\begin{array}{c}\text { Safety Management } \\
\text { and Labor of heatlh }\end{array}$ & Frequency & Percentage \\
\hline 1 & Less & 19 & 63.3 \\
\hline 2 & Enough & 2 & 6.7 \\
\hline 3 & Good & 9 & 30 \\
\hline & Total & $\mathbf{3 0}$ & $\mathbf{1 0 0}$ \\
\hline
\end{tabular}

The results showed that the number of respondents of 30 health centers. Based on the results as shown in the table above shows that more than half the health center has a Health and Safety Management lacking health center as much as 19 respondents $(63.3 \%)$.

Table 4. Logistic Regression Between Infrastructure Competence in Occupational Safety and Health Management Implementation work at Puskesmas District of Tulungagung $(n=30)$

Model Fitting Information

\begin{tabular}{ccccc}
\hline Model & -2 Log Likelihood & Chi-Square & df & Sig. \\
\hline Only Intercept & 17.298 & & & \\
\hline Final & 15.141 & 2.157 & 2, & 340 \\
\hline
\end{tabular}

Link function: Logit.

Results of statistical test was performed using ordinal regression tests to 30 health center respondents using error degrees obtained $p$ value of 0.05 and 0.340 , if the $p$ value <degree of culpability, the $\mathrm{H} 1$ is received or no effect, but if the $\mathrm{p}$ value> degrees errors then $\mathrm{H} 0$ or no significant effect. So $\mathrm{p}$ value $<0.05$, then $\mathrm{H} 0$ is accepted, meaning that there is no influence of infrastructure and personnel competence to the implementation of occupational safety and health management (MK3).

\begin{tabular}{lr}
\hline & Pseudo R-Square \\
\hline Cox and & Snell,069, \\
\hline Nagelkerke & 086 \\
\hline McFadden, & 043 \\
\hline Link function: Logit. &
\end{tabular}


Statistical test results in this study was obtained Pseudo R-square value amounted to 0.086 at Nagelkerke this means that infrastructure and competence in explaining the implementation of the MK3 by 0.086 or $8.6 \%$ and there is a $100 \%-8.6 \%=91.4 \%$ other factors beyond model that describes the implementation of the MK3.

\section{DISCUSSION}

Based on the results of research on the parameter estimates shows that the infrastructure and the competence of the implementation of MK3, it can be seen from Wald statistic values which have significantly smaller than $0.05(<0.05)$, which means each variable influence on MK3. The results showed that less than half of the respondents Health Center have facilities and the MK3 complete Health and Safety Management which is less by 13 respondents $(43.3 \%)$. The results also show that there is one health center respondents $(3.3 \%)$ have the means and the Management of Health and Safety is lacking. Statistical test using values obtained Chi Square correlation $\rho$-value $=0.353$ with a confidence level of $95 \%(\alpha=$ 0.05 ) means that there is no effect between infrastructure MK3 with Occupational Health and Safety Management.

Result showed that more than half of respondents have a health center personnel with competence K3 untrained and Occupational Health and Safety Management which is less by 16 respondents $(53.3 \%)$. The results also showed that there were 2 respondents Puskesmas (6.7\%) have the power to K3 and Competence Management Occupational Health and Safety was good. Statistical test using values obtained Chi_Square correlation $\rho$-value $=0.028$ with a confidence level of $95 \%(\alpha=0.05)$ means that there is influence of personnel with competence K3 with Occupational Health and Safety Management.

Results of statistical test was performed using ordinal regression tests to 30 health center respondents using error degrees obtained $p$ value of 0.05 and 0.340 , if the $p$ value <degree of culpability, the $\mathrm{H} 1$ is received or no effect, but if the $\mathrm{p}$ value> degrees errors then $\mathrm{H} 0$ or no significant effect. So, $\mathrm{p}$ value $<0.05$, then $\mathrm{H} 0$ is accepted, meaning that there is no influence of infrastructure and personnel competence to the implementation of occupational safety and health management (MK3).

Statistical test results in this study was obtained Pseudo R-square value amounted to 0.086 at Nagelkerke this means that infrastructure and competence in explaining the implementation of the MK3 by 0.086 or $8.6 \%$ and there is a $100 \%-8.6 \%=91.4 \%$ other factors beyond model that describes the implementation of the MK3.

Statistical test results in table parameter estimates shows that the infrastructure and the competency of the implementation of the MK3, it can be seen from the statistical value Wald $(0,012)$, which has a significantly smaller than $0.05(<0.05)$, which means that each each variable give effect to the partial MK3.

Concepts relate to the cause of the accident sequence of the history of the development of Occupational Health and Safety (K3) daro beginning until today. All a concept model of the cause of the accident development today's most recently applied, but then at some point turn the initial concept as a fad. Nowadays, especially in large company's health and safety becomes global demand. At some point it will return to the original concept that is moved at the dominance of human error / unsafe action or back into human behavior. Another thing that stands out is the presence of an iceberg in accident costs, the incidence rate of incident and cause-effect accompanying the emergence of incident (Riyadi,2007).

International Loss Control Institute (Ilci) in 1972, spearheaded by Frank E bird theorized Caution Loss Model stating that management is a background factor or cause accidents. The theory is found HW Heinrich. Frank E Bird describe how modern thinking occurrence of defect / Many are used as the basis of thinking for the prevention of accidents (Riyadi, 2007) andshows that control in the form of systems, standards and compline may cause the underlying problems. Problembase on personal factors and also factors working system. This can lead to cause immediate and eventually become accidents. This condition is the need for prevention efforts to reduce workplace accidents so as not further risk or workplace accidents. 
According to Frank E Bird main causes of human factors (lack of knowledge, lack of motivation, lack of skills, physical or mental problems, an ability that is not enough physically and mentally). Occupational factors (Quality standard of work inadequate, and Design abnormal and others), direct causes (Actions unsafe situation unsafe work)

Incident (event) is meeting a source of energy (kinetic energy, electrical, acoustic, thermal, radiation, chemical and others) that exceeds the threshold value the ability of the body or structure, such as excessive load, contact hazardous energy sources. Loss (Loss) is a human loss of property and the production process at the company's image. Costs incurred from the incident as an iceberg. In Caution Loss Model shows that the loss (loss) whatever happens because of imbalance experienced by something. Imbalances occur ecause something abnormal events for their direct, then if there traced essentially coming from the weak control depends on how and where it happened. The size of the losses suffered because of an accident will depend on the causes that exist. If categorized variations accident from someone scratched fingers until destruction of a refinery as well as the human toll in large quantities. Many are already examples of accidents suffered major industry in the world that suffer substantial losses include materials, machines, humans and the surrounding environment (Riyadi, 2007).

Based on the research that the infrastructure and personnel competence no effect implementation of health and safety management, there is no influence between infrastructure MK3 with Occupational Health and Safety Management. Yet Significant relationship between K3 Competency Management Officer with the Occupational Safety and Health. Competence of health workers will affect the behavior, attitudes and actions against work accidents. Many Puskesmas Tulungagung who have less MK3 implementation is supported by at least force have the competence K3. It accordance with Salawati study (2009) that the incidence of workplace accidents have a relationship with the behavior of knowledge, attitudes and actions associated with accidents.

\section{REFERENCES}

Depkes. (2004). Keputusan Menteri Kesehatan RI Nomor 128/MENKES/SK/II/2004 tentang Kebijakan Dasar Pusat Kesehatan Masyarakat. Jakarta: Depkes RI.

Dinkes. (2013). Pengantar Kesehatan Kerja, Bidang Yankes Dinkes Kota Pasuruan. Available at: https://yankeskotapas.wordpress.com/2013/04/17/pengantar-kesehatan-kerja/ (Accessed: 2 March 2017).

Hasibuan, M. (2000). Manajemen Sumber Daya Manusia. STIE YKPN.

ILO. (2005). A Global Alliance Against Forced Labour. Geneva: Internasional Labour Conference 93rd Session 2005.

Kawatu. (2012). 'Bahan Kuliah Kesehatan Keselamatan Kerja. Fakultas Kesehatan Masyarakat', Universitas Sam Ratulangi Manado, 1(1), p. 1.

Kemenkes. (2007). Keputusan Menteri Kesehatan Republik Indonesia Nomor 377/Menkes/SK/III/2007 Tentang Standar Profesi Perekaman Medis dan Informasi Kesehatan.

Kurniawidjaja. (2010). Teori dan Aplikasi Kesehatan Kerja. Jakarta: Ui Press.

Lusianawaty, T. (2013). 'Penerapan Kesehatan dan Keselamatan Kerja di Puskesmas di Tiga Provinsi di Indonesia’, Buletin Penelitian Kesehatan, 41(3).

Matondang. (2008). Kepemimpian budaya organisasi dan menejemen strategik. Yogyakarta: Graha Ilmu. 
Muninjaya, G. (2004). Manajemen Kesehatan. Jakarta: EGC.

Notoatmodjo. (2010). Promosi Kesehatan dan Ilmu Perilaku. Jakarta: Rineka Cipta.

Nursalam. (2008). Konsep dan penerapan metodologi penelitian ilmu keperawatan. Jakarta: Salemba Medika.

Permenkes. (2014). Peraturan Menteri Kesehatan Republik Indonesia Nomor 75 Tahun 2014 tentang Pusat Kesehatan Masyarakat. Jakarta: Permenkes RI.

Rahayuningsih, P. W. (2010). 'Penerapan Manajemen Keselamatan dan Kesehatan Kerja (MK3) di Instalasi Gawat Darurat RSU PKU Muhammadiyah Yogyakarta', Kesehatan Masyarakat, 1(1), pp. 21-29.

Riyadi, S. (2007). Keperawatan Keseahatan Masyarakat. Jakarta: PT Raja Grafindo Persada. 